\title{
Intracellular bactericidal effects of rifampicin in both normal and chronic granulomatous disease polymorphs
}

\author{
G. EZER and J. F. SOOTHILL \\ From the Department of Immunology, Institute of Child Health, London
}

\begin{abstract}
Ezer, G., and Soothill, J. F. (1974). Archives of Disease in Childhood, 49, 463. Intracellular bactericidal effects of rifampicin in both normal and chronic granulomatous disease polymorphs. Chronic granulomatous disease (CGD) polymorphs incubated with rifampicin before or after staphylococcal phagocytosis inactivated the bacteria. Lysates of normal polymorphs incubated with rifampicin inactivated bacteria. These effects were not due to damage to the polymorphs.

Polymorph lysates of rifampicin-treated CGD patients and healthy subjects inactivated bacteria, but the polymorphs of rifampicin-treated CGD patients did not kill the bacteria in vitro.

The role of rifampicin in the treatment of CGD patients and of other patients with intracellular infections is discussed.
\end{abstract}

In chronic granulomatous disease (CGD) the polymorphs and macrophages phagocytose normally, but certain organisms are not killed after phagocytosis. Children with this defect get frequent lymphadenitis, pneumonia, liver abscesses, and skin sepsis (Berendes, Bridges, and Good, 1957; Landing and Shirkey, 1957). Organisms often cultured from the lesions include Staphylococcus aureus, Enterobacter aerogenes, Esch. coli, Serratia marcescens, Candida albicans, and Aspergillus fumigatus. It has been suggested that organisms surviving in CGD polymorphs are catalase positive ones (Kaplan, Laxdal, and Quie, 1968).

Holmes and co-workers (1966) and Alexander and Good (1968) have shown that the bacteria phagocytosed by CGD polymorphs are protected from antibiotics in the culture medium, because they do not enter the cells. They studied chloramphenicol, oxytetracycline, ampicillin, methicillin, penicillin, streptomycin, and erythromycin. It is likely that this contributes to the limited effect of antibiotics in these patients.

Rifampicin has been used for the treatment of tuberculosis and coccal infections, especially chronic meningococcal carriers (Deal and Sanders, 1969). Since the drug is effective in infections involving intracellular organisms like Mycobacterium tuber-

Received 12 November 1973.

^Present address : Cerrahpasa Cocuk Klinigi, Istanbul, Turkey. culosis, Dr. A. C. Allison suggested its possible use in the treatment of CGD patients. We have therefore studied its capacity to kill bacteria surviving in CGD polymorphs and its capacity to enter normal polymorphs, in order to provide a basis for its possible use in treating CGD patients and an explanation of its role in treating other intracellular infections.

\section{Materials and methods}

The 5 patients studied were boys, aged 4 to 16 years, with typical clinical history of CGD and defective polymorph bacterial killing (see Table I), and nitro blue tetrazolium (NBT) reduction after latex phagocytosis. Cases 3 and 5 were reported by Thompson and Soothill (1970). The others are unpublished.

A polymorph-rich cell suspension was prepared from heparinized blood by sedimentation with $6 \%$ dextran solution at room temperature for $\mathbf{4 5}$ minutes. Oxford strain of staphylococcus was cultured for 24 hours in nutrient broth medium before use. The minimum inhibition concentration for rifampicin $(<0.005 \mathrm{mg} / \mathrm{ml})$ and blood level of rifampicin were measured by tube dilution method (Bryant, 1968). Rifampicin $1 \mathrm{mg} / \mathrm{ml}$ was dissolved in $\mathrm{M} / 15$ phosphate buffer $p \mathrm{H} 7 \cdot 4$ and $20 \%$ methanol and diluted with buffer to $0.05,0.5$, and 5 $\mu \mathrm{g} / \mathrm{ml}$.

Bactericidal test was done by the method of Quie et al. (1967). The bacteria and polymorphs were cultured for 20 minutes in Hanks's medium containing fresh human serum for phagocytosis to take place. The polymorphs were then washed, an aliquot was lysed, and the viable 
TABLE I

Bacterial killing by normal and CGD polymorphs in different antibiotics

\begin{tabular}{|c|c|c|c|c|}
\hline \multirow{3}{*}{$\begin{array}{c}\text { Case and control } \\
\text { no. }\end{array}$} & \multicolumn{4}{|c|}{$140 \mathrm{~min} / 20 \mathrm{~min}$ bacterial count } \\
\hline & \multicolumn{2}{|c|}{ Normal polymorph } & \multicolumn{2}{|c|}{ CGD polymorph } \\
\hline & Penicillin + streptomycin & Rifampicin & Penicillin + streptomycin & Rifampicin \\
\hline $\begin{array}{l}1 \\
2 \\
3 \\
4 \\
5\end{array}$ & $\begin{array}{l}0.003 \\
0 \cdot 02 \\
0 \cdot 07 \\
0 \cdot 17 \\
0.05\end{array}$ & $\begin{array}{l}0 \cdot 01 \\
0 \cdot 03 \\
0 \cdot 09 \\
0 \cdot 10 \\
0 \cdot 04\end{array}$ & $\begin{array}{l}0 \cdot 76 \\
0 \cdot 85 \\
0 \cdot 90 \\
1 \cdot 57 \\
0 \cdot 48\end{array}$ & $\begin{array}{l}0 \cdot 18 \\
0 \cdot 13 \\
0 \cdot 19 \\
0 \cdot 50 \\
0 \cdot 37\end{array}$ \\
\hline
\end{tabular}

bacteria in them were counted by the pour plate technique. Others were cultured for a further 120 minutes in Hanks's medium containing either penicillin $(0.06 \mathrm{mg} / \mathrm{ml})+$ streptomycin $(0.14 \mathrm{mg} / \mathrm{ml})$ or rifampicin $(0.5 \mu \mathrm{g} / \mathrm{ml})$. The values for each antibiotic system are expressed as the number of surviving organisms at 140 minutes over the number at 20 minutes. If no killing took place, the ratio would be 1 . Viability of polymorph was tested by trypan blue exclusion and the quantitative NBT test (Baehner and Nathan, 1968).

Statistical analysis was by paired ' $t$ ' test.

\section{Results}

The bacterial killing (number at $140 \mathrm{~min} /$ number at $20 \mathrm{~min}$ ) in normal and CGD polymorphs, in medium containing either penicillin + streptomycin or rifampicin, are shown in Table I. Each patient and the healthy subject studied in parallel with him are on the same line in Table I. Normal polymorphs gave similar values with each medium $(t=0.53, \quad P>0.6)$. With penicillin and streptomycin little bacterial killing took place in CGD polymorphs, but in medium containing rifampicin $0.5 \mu \mathrm{g} / \mathrm{ml}$, significantly more killing occurred $(t=4 \cdot 11, P<0 \cdot 005)$. Incubation of normal polymorphs in medium containing rifampicin 0.5 and $5 \mu \mathrm{g} / \mathrm{ml}$ for 2 hours did not apparently affect trypan blue exclusion or NBT reduction after stimulation by. latex particle phagocytosis (Table II).

Rifampicin could be detected by bacterial killing in CGD polymorphs preincubated in medium containing rifampicin. CGD polymorphs were similarly preincubated in medium with or without 5 $\mu \mathrm{g} / \mathrm{ml}$ rifampicin for 2 hours; they were then washed and incubated with bacteria for 20 minutes. The intracellular bacteria were counted in aliquots (numbers about fourfold lower than untreated polymorphs, presumably because of the effect of the intracellular antibiotic) and others were incubated in penicillin and streptomycin for a further 120 minutes. Further bacterial killing occurred (Table III) in those preincubated in rifampicin but not in those preincubated in Hanks's medium.

Rifampicin could also be detected, by bacterial killing, in lysates of normal polymorphs preincubated in rifampicin.

Normal polymorphs were incubated at $37^{\circ} \mathrm{C}$ for 2 hours in Hanks's medium alone, and with either penicillin and streptomycin or rifampicin $5 \mu \mathrm{g} / \mathrm{ml}$. The cells were washed three times, and lysed with distilled water and vigorous pippetting. The lysates were centrifuged at 3000 r.p.m. for $15 \mathrm{~min}$, $3 \times 10^{6}$ bacteria were added, and viable bacteria were counted at once and 1 hour later. The previous study had shown that most bacterial inactivation by rifampicin had occurred by this time. Lysates of polymorphs incubated in rifampicin killed the bacteria $(t=6 \cdot 5, P<0 \cdot 001)$, but those incubated in Hanks's with or without penicillin +streptomycin did not differ significantly $(t=1 \cdot 1, P=0 \cdot 3)$ (Table IV). This effect was still detectable in lysates of rifampicin preincubated polymorphs

TABLE II

Viability of normal polymorphs after preincubation

\begin{tabular}{c|c|c|c|c|c}
\hline \multicolumn{3}{c|}{ Trypan blue exclusion \% positive cells } & \multicolumn{3}{c}{ NBT reduction $\Delta$ OD } \\
\hline Hanks's & Rifampicin $0.5 \mu \mathrm{g} / \mathrm{ml}$ & Penicillin + streptomycin & Hanks's & Rifampicin $0.5 \mu \mathrm{g} / \mathrm{ml}$ & Rifampicin $5 \mu \mathrm{g} / \mathrm{ml}$ \\
\hline 18 & 9 & 8 & $0 \cdot 18$ & 0.23 \\
3 & 2 & 4 & 0.20 & 0.31 \\
8 & 6 & 4 & - & 0.29 \\
\hline
\end{tabular}


TABLE III

Bacterial killing by CGD polymorphs after preincubation in rifampicin

$140 \mathrm{~min} / 20 \mathrm{~min}$ bacterial count

\begin{tabular}{c|c}
\hline $\begin{array}{c}\text { Preincubation in Hanks's } \\
\text { medium }\end{array}$ & Preincubation in rifampicin \\
\hline $1 \cdot 10$ & $0 \cdot 27$ \\
$1 \cdot 12$ & $0 \cdot 37$ \\
\hline
\end{tabular}

TABLE IV

Bactericidal action of lysates of normal polymorphs preincubated with antibiotics

\begin{tabular}{c|c|c}
\hline \multicolumn{2}{c}{$60 \mathrm{~min} / 0 \mathrm{~min}$ bacterial count } \\
\cline { 2 - 3 } Penicillin + streptomycin & Hanks's solvent & Rifampicin \\
\hline 1.62 & $1 \cdot 51$ & 0.26 \\
1.27 & $1 \cdot 76$ & 0.06 \\
0.76 & $1 \cdot 22$ & 0.27 \\
1.20 & $1 \cdot 33$ & 0.24 \\
1.28 & $1 \cdot 10$ & 0.40 \\
& & \\
\hline
\end{tabular}

which had been washed and reincubated for 1 hour without rifampicin in the medium.

Two patients with CGD and 2 healthy adults were given rifampicin $20 \mathrm{mg} / \mathrm{kg} 3$ hours before bleeding; their blood levels, shown in Table V, are all in the therapeutic range. The dye exclusion test showed no evidence of polymorph damage, and their lysates killed the bacteria, but the bacterial killing by the CGD polymorphs treated in vivo with rifampicin was not obviously better than that of untreated cells (see Cases 1 and 3-Table I).

Two patients with CGD were treated with rifampicin $(20 \mathrm{mg} / \mathrm{kg}$ per day in divided doses) at a time of infective illness. No microbiological diagnosis was possible pretreatment. 1 developed a groin lymph node lesion, after a series of other lesions involving lymph nodes in liver and skin from which a staphylococcus had been cultured, so it is likely that the new lesion was staphylococcal. Local and general evidence of infection cleared, and no further lesions occurred during the 2 weeks on rifampicin, or soon after stopping it. The other boy had lung lesions, which did not respond to rifampicin. It was later diagnosed on indirect evidence as being due to Aspergillus fumigatus.

\section{Discussion}

We have shown that rifampicin enters normal and CGD polymorphs, and, taking advantage of the special property of the latter that bacteria survive in them, have shown that it will kill intracellular bacteria. Bacteria are killed in CGD polymorphs both when rifampicin is added to the medium after phagocytosis has occurred and when the polymorphs are preincubated with it, before phagocytosis.

One possible explanation of this is that rifampicin might enter the cells as a result of its toxic damage to the cell. The observation that bacterial killing in normal polymorphs in rifampicin is better than that of CGD polymorphs in rifampicin, suggests that the normal bactericidal mechanisms are at least partly intact. Also NBT test and trypan blue dye exclusion results were normal after 2 hours incubation with the antibiotic and normal bacterial phagocytosis occurred. Hoeprich and Martin (1970) previously showed that rifampicin did not interfere with phagocytosis and killing of a strain of Esch. coli resistant to rifampicin.

Lysates of normal polymorphs preincubated in rifampicin inactivate bacteria. This indicates that it can penetrate into these too. Rifampicin is highly soluble in lipids and this may be related to its ability to penetrate the cell membrane. The bactericidal effect of lysates was still detectable after washing the cells and reincubation for 1 hour without rifampicin in the medium, so it is unlikely to be an effect of rifampicin loosely bound to the surface of the cell.

Since this work was started, Mandell and Vest (1972) have reported that selected pathogenic staphylococci, which can survive unusually long

TABLE V

Polymorph tests on rifampicin-treated CGD and healthy subjects

\begin{tabular}{|c|c|c|c|c|}
\hline Polymorph & $\begin{array}{c}\text { Rifampicin blood level } \\
(\mu \mathrm{g} / \mathrm{ml})\end{array}$ & $\begin{array}{c}\text { Trypan blue } \% \text { positive } \\
\text { polymorphs }\end{array}$ & $\begin{array}{l}\text { Polymorph lysate } \\
\text { bacterial killing } \\
(60 \mathrm{~min} / 0 \mathrm{~min})\end{array}$ & $\begin{array}{c}\text { Polymorph bacterial } \\
\text { killing } \\
(140 \mathrm{~min} / 20 \mathrm{~min})\end{array}$ \\
\hline $\begin{array}{l}\text { Treated CGD } \\
\text { Treated healthy } \\
\text { Untreated healthy } \\
\text { Treated CGD } \\
\text { Treated healthy } \\
\text { Untreated healthy }\end{array}$ & $\begin{array}{r}2 \cdot 5 \\
5 \cdot 0 \\
14 \cdot 0 \\
=14 \cdot 0\end{array}$ & $\begin{array}{l}4 \\
5 \\
2 \\
1\end{array}$ & $\begin{array}{l}0 \cdot 20 \\
0 \cdot 15 \\
1 \cdot 3 \\
0 \cdot 10 \\
0 \cdot 11 \\
1 \cdot 28\end{array}$ & $\begin{array}{l}0.90 \\
0.01 \\
0.03 \\
0.58 \\
0 \cdot 10 \\
0.02\end{array}$ \\
\hline
\end{tabular}


after phagocytosis by normal polymorphs, are killed if the bacteria containing polymorphs are incubated in media containing rifampicin. In studies with 18 isotope labelled antibiotics, Mandell (1973) detected radioactivity in polymorphs only with rifampicin. This last experiment establishes its exceptional properties relating to entry of cells, but does not establish that the antibiotic had done so in an active form. Our studies with CGD polymorphs show that intracellular killing by rifampicin can occur essentially in the absence of physiological killing, and the studies of lysates of normal polymorphs confirm that the drug entering the polymorph is indeed active.

These findings suggest that this drug might have a special place in treating CGD patients infected with rifampicin-sensitive organisms. Previous attempts to gain access to the organisms surviving inside CGD polymorphs have included the use by Thompson and Soothill (1970) of busulphan in the hope of destroying the infected polymorphs, and so exposing the ingested bacteria to humoral bactericidal effect and to antibiotics. McCrae and Raeburn (1972) used clofazimine and co-trimoxazole in an attempt to improve the leucocyte function. There is no clear evidence that either measure was useful.

The one CGD patient we have treated with rifampicin who may have had a rifampicin-sensitive infection appeared to respond to the drug. Since staphylococci become resistant to the drug very rapidly (McCabe and Lorian, 1968), we think that it should always be given with another antibiotic, though we did not do so in this case. The failure to detect bacterial killing in the lysates of the polymorphs of the other treated patient, while on 3 divided doses, when the blood level of the drug was low, suggests that any possible intracellular effects may be achieved only if large intermittent doses are given. No evidence of toxicity was noted, but the frequency of allergic reactions to rifampicin, particularly when given intermittently, and the special susceptibility of CGD patients to drug allergies suggest that there may be a special risk.

We do not know why the polymorphs of the rifampicin-treated CGD patients did not kill bacteria in vitro. One possible explanation, for which we have not been able to devise an appropriate control, is that the drug leaves the polymorphs and becomes attached to other blood factors during the period of cell separation.

These findings may well be of significance beyond CGD patients. They represent a possible explanation of the eradication of the meningococcus from resistant carriers by rifampicin (Deal and
Sanders, 1969; Jones, Tobin, and Butterworth, 1973). Copeland and co-workers (1971) showed that the bactericidal activity of polymorphs from patients with severe bacterial infections was impaired. Rifampicin may have a special role in this situation, too.

We feel that the evidence presented here that this antibiotic does enter the polymorphs justifies its therapeutic use in CGD patients with bacterial infections sensitive to it, and goes some way to explain its special usefulness in other patients with intracellular bacterial infections.

\section{REFERENCES}

Alexander, J. W., and Good, R. A. (1968). Effect of antibiotics on the bactericidal activity of human leucocytes. Fournal of Laboratory and Clinical Medicine, 71, 971.

Baehner, R. L., and Nathan, D. G. (1968). Quantitative nitroblue tetrazolium test in chronic granulomatous disease. New England Fournal of Medicine, 278, 971.

Berendes, H., Bridges, R. A., and Good, R. A. (1957). A fatal granulomatosis of childhood: the clinical study of a new syndrome. Minnesota Medicine, 40, 309.

Bryant, M. C. (1968). Antibiotics and Their Laboratory Control, p. 58. Butterworth, London.

Copeland, J. L., Karrh, L. R., McCoy, J., and Guckian, J. C. (1971). Bactericidal activity of polymorphonuclear leucocytes from patients with severe bacterial infections. Texas Reports on Biology and Medicine, 29, 555.

Deal, W. B., and Sanders, E. (1969). Efficacy of rifampin in treatment of meningococcal carriers. New England fournal of Medicine, 281, 641.

Hoeprich, P. D., and Martin, C. H. (1970). Effect of tetracycline, polymixin $\mathrm{B}$, and rifampin on phagocytosis. Clinical Pharmacology and Therapeutics, 11, 418.

Holmes, B., Quie, P. G., Windhorst, D. B., Pollara, B., and Good, R. A. (1966). Protection of phagocytized bacteria from the killing action of antibiotics. Nature, $210,1131$.

Jones, D. M., Tobin, B. M., and Butterworth, A. (1973). Three cases of meningococcal infection in a family associated with a deficient immune response. Archives of Disease in Childhood, 48,742 .

Kaplan, E. L., Laxdal, T., and Quie, P. G. (1968). Studies of polymorphonuclear leucocytes from patients with chronic granulomatous disease of childhood: bactericidal capacity for streptococci. Pediatrics, 41, 591.

Landing, B. H., and Shirkey, H. S. (1957). A syndrome of recurrent infection and infiltration of viscera by pigmented lipid histiocytes. Pediatrics, 20, 431.

McCabe, W. R., and Lorian, V. (1968). Comparison of the antibacterial activity of rifampicin and other antibiotics. American fournal of the Medical Sciences, 256, 255.

McCrae, W. M., and Raeburn, J. A. (1972). Chronic granulomatous disease: an attempt to stimulate phagocytic activity. Lancet, 1, 1370.

Mandell, G. L. (1973). Interaction of intraleukocytic bacteria and antibiotics. Fournal of Clinical Investigation 52, 1673.

Mandell, G. L., and Vest, T. K. (1972). Killing of intraleukocytic Staphylococcus aureus by rifampin: in-vitro and in-vivo studies. Fournal of Infectious Diseases, 125, 486.

Quie, P. G., White, J. G., Holmes, B., and Good, R. A. (1967). In vitro bactericidal capacity of human polymorphonuclear leucocytes: diminished activity in chronic granulomatous disease of childhood. Fournal of Clinical Investigation, 46, 668.

Thompson, E. N., and Soothill, J. F. (1970). Chronic granulomatous disease: quantitative clinicopathological relationships. Archives of Disease in Childhood, 45, 24.

Correspondence to Professor J. F. Soothill, Department of Immunology, Institute of Child Health, 30 Guilford Street, London WC1N 1EH. 